\title{
SUHU PERMUKAAN LAUT DAN KEDALAMAN TERTANGKAPNYA TUNA OLEH KAPAL PANCING ULUR YANG DILENGKAPI LAMPU
}

\section{THE SEA SURFACE TEMPERATURE AND DEPTH OF CAAUGHT BY HAND LINER EQUIPPED LAMPS}

\author{
Rama Agus Mulyadi ${ }^{1}$, Muhammad Fedi Alfiadi Sondita ${ }^{2}$, Roza Yusfiandayani ${ }^{2}$ \\ ${ }^{1}$ Program Studi Teknologi Perikanan Laut, Sekolah Pascasarjana \\ ${ }^{2}$ Departemen Pemanfaatan Sumberdaya Perikanan, \\ Fakultas Perikanan dan Ilmu Kelautan, Institut Pertanian Bogor \\ Korespondensi: ramaagus17@yahoo.com, fsondita@yahoo.com,ocha.ipb@gmail.com
}

\begin{abstract}
The movements and abundance of tuna are strongly influenced by the temperature and water depth. Bungus-based fishermen catch bigeye tuna (BET, Thunnus obesus) and yellowfin tuna (YFT, Thunnus albacares) using handlines operated on light-equipped fishing boats. Purpose of the research : (1) to measure the sea surface temperature (SST) and swimming layer bigeye tuna (BET) and yellowfin tuna (YFT) around Mentawai Island, (2) to identification the effect of light on the vertical distribution, and (3) to determine length of hookline the best catch tuna. Based on the length of the line and configuration of line, weight, hooks and live-squid baits, their hooks were at 45, 53, 60, and 68 meters below sea surface. A total of 8 YFT were caught at 45, 53 and $60 \mathrm{~m}$ depths; their total weight was $354 \mathrm{~kg}$. One BET of $45 \mathrm{~kg}$ was caught at $60 \mathrm{~m}$ depth. This study confirmes that these large-sized tunas were caught at a swimming layer of 15-60 m depth. The sea surface temperature (SST) in the fishing ground around Mentawai Island was $28.9^{\circ} \mathrm{C}$ in average where fishermen successfuly caught a total of 15 tunas consisting of 3 BETs and 12 YFT. Adult tuna were caught mostly at 23-60 m depth while the juveniles were caught at 15-45 m. This research indicated an effect of light on increasing the position of adult tuna swimming layer. Handline with line of $53 \mathrm{~m}$ is the best gear for catching adult tuna in the area.
\end{abstract}

Keyword: swimming layer, handline, tuna, Mentawai

\begin{abstract}
ABSTRAK
Sebaran dan kelimpahan ikan tuna sangat dipengaruhi oleh suhu dan kedalaman air. Nelayan tuna Bungus menangkap ikan tuna bigeye (BET, Thunnus obesus) dan tuna sirip kuning (YFT, Thunnus albacares) menggunakan pancing ulur yang dioperasikan pada kapal yang dilengkapi lampu sebagai alat abantu. Tujuan penelitian: (1) mengukur suhu permukaan laut (SST) dan kedalaman renang tuna mata besar dan tuna sirip kuning di sekitar Pulau Mentawai, (2) mengidentifikasi pengaruh cahaya terhadap sebaran vertikal tuna, dan (3) menentukan panjang tali pancing terbaik untuk penangkapan tuna. Berdasarkan panjang garis dan konfigurasi garis, berat, kait dan umpan cumi-cumi, kait mereka berada di 45, 53, 60, dan 68 meter di bawah permukaan laut. Sebanyak 8 tuna sirip kuning tertangkap di kedalaman 45, 53 dan 60 m; berat total $354 \mathrm{~kg}$. Satu BET seberat $45 \mathrm{~kg}$ tertangkap pada kedalaman $60 \mathrm{~m}$. Penelitian ini memberitahukan bahwa tuna berukuran besar tertangkap di lapisan permukaan dengan kedalaman 15-60 m. Suhu permukaan laut (SST) di daerah penangkapan ikan di sekitar Pulau Mentawai rata-rata $28.97{ }^{\circ} \mathrm{C}$ di mana nelayan berhasil menangkap 15 tuna yang terdiri dari 3 ekor tuna mata besar dan 12 ekor tuna sirip kuning. Tuna dewasa kebanyakan tertangkap pada kedalaman 23-60 m sedangkan muda tertangkap di kedalaman 15-45 m. Penelitian ini menunjukkan pengaruh cahaya dapat menaikkan posisi lapisan renang tuna dewasa. Handline dengan panjang tali $53 \mathrm{~m}$ adalah panjang tali terbaik untuk menangkap tuna dewasa di daerah tersebut.
\end{abstract}

Kata kunci: kedalaman renang, pancing ulur, tuna, Mentawai 


\section{PENDAHULUAN}

Sebaran ikan tuna sangat dipengaruhi oleh beberapa faktor, dua di antaranya adalah suhu dan kedalaman renang (swimming layer) tuna (Nakamura 1969). Mempertimbangkan dua faktor tersebut, nelayan tuna harus tepat dalam menentukan lokasi penangkapan ikan dan kedalaman pancing yang diturunkan. Menurut Diniah et al. (2001), penangkapan tuna di Indonesia umumnya menggunakan huhate (pole and line), pancing ulur (handline), dan rawai tuna (tuna longline).

Berdasarkan citra echosounder, Nurdin (2017) menyatakan bahwa pada kedalaman 50-70 $\mathrm{m}$ ada tuna yang berukuran 30 - $50 \mathrm{~cm}$ (FL) sedangkan pada kedalaman 300 - $400 \mathrm{~m}$ ada tuna yang berukuran 100 - 120 cm (FL), baik pagi maupun siang hari. Tanpa spesifik menyebutkan panjang ikan, Barata et al. (2011) melaporkan tertangkapnya tuna sirip kuning (yellowfin tuna - YFT, Thunnus albacares) dewasa pada kedalaman 80 $170 \mathrm{~m}$ dan bersuhu $22.20{ }^{\circ} \mathrm{C}-26.40{ }^{\circ} \mathrm{C}$ sedangkan tuna mata besar (bigeye tunaBET, Thunnus obesus) tertangkap pada kedalaman 190 - 500 m dengan suhu 8.35 ${ }^{\circ} \mathrm{C}-15.30{ }^{\circ} \mathrm{C}$. Nugraha \& Triharyuni (2009) melaporkan bahwa BET banyak tertangkap pada kedalaman 300-400 m yang bersuhu 10 ${ }^{\circ} \mathrm{C}-13.9^{\circ} \mathrm{C}$ sedangkan YFT pada kedalaman 150 - $199 \mathrm{~m}$ yang bersuhu $20{ }^{\circ} \mathrm{C}-20.9{ }^{\circ} \mathrm{C}$. Ketiga penelitian tersebut menunjukkan bahwa tuna berukuran besar cenderung tertangkap pada posisi lebih dalam dari $100 \mathrm{~m}$ di bawah permukaan laut. Menurut Sjarif et al. (2012), tuna banyak tertangkap mulai dari kedalaman 200 m hingga batas atas daerah termoklin. Pickard \& Emery (1990) membedakan kedalaman air di mana tuna ditangkap menjadi dua, yaitu lapisan dangkal untuk kedalaman 0 - 100 m di mana tuna berukuran kecil biasa tertangkap dan lapiran termoklin untuk kedalaman 100-200 $\mathrm{m}$ di mana tuna dewasa biasa tertangkap (Gambar 1).

Howell et al. (2010) menyatakan pergerakan tuna pada siang hari berada pada kedalaman 200 - 400 m dan malam hari pada kedalaman 0 - 200 m. Adanya kedalaman renang tuna pada saat siang dan malam hari karena ikan-ikan pelagis mengandalkan zooplankton sebagai mangsanya dan akan mengikuti pola sebaran vertikal zooplankton tersebut. Selanjutnya, rantai makanan yang berbasis zooplankton akan memiliki pola distribusi vertikal yang berhubungan erat dengan pola sebaran vertikal zooplankton tersebut. Saat siang hari ketika matahari dalam posisi tertinggi, zooplankton cenderung menjauh dari permukaan laut untuk menghindari ultra violet yang dapat merusak tubuhnya dan akan mendekati permukaan laut ketika matahari pada posisi rendah, yaitu beberapa saat setelah matahari terbit atau menjelang tenggelam.

Penggunaan cahaya sebagai alat bantu penangkapan ikan di malam hari diperkirakan dapat memengaruhi arah renang ikan dan merubah posisi swimming layer sehinggaikan mendekat dan berkumpul di dekat sumber cahaya membangun suatu rantai makanan sementara (temporary food chain).

Fenomena naiknya tuna besar ke lapisan dangkal kemungkinan terjadi selama proses penangkapan tuna yang dilakukan oleh nelayan tuna yang berbasis di Bungus, Sumatera Barat. Mereka menggunakan pancing ulur (handline) berumpan cumicumi hidup dan cahaya lampu listrik di atas kapal. Metode penangkapan ikan demikian diperkirakan akan menyebabkan tuna berukuran besar (40-80 kg) yang biasa tertangkap pada kedalaman di bawah $100 \mathrm{~m}$ juga banyak tertangkap oleh pancing pada kedalaman di atas $100 \mathrm{~m}$.

Tujuan dari penelitian ini adalah untuk mengukur kondisi suhu permukaan laut dan kedalaman renang tuna mata besar dan sirip kuning di perairan pulau Mentawai, mengidentifikasi pengaruh lampu terhadap sebaran vertikal tuna, dan menentukan panjang tali pancing terbaik untuk penangkapan tuna dengan bantuan lampu. 


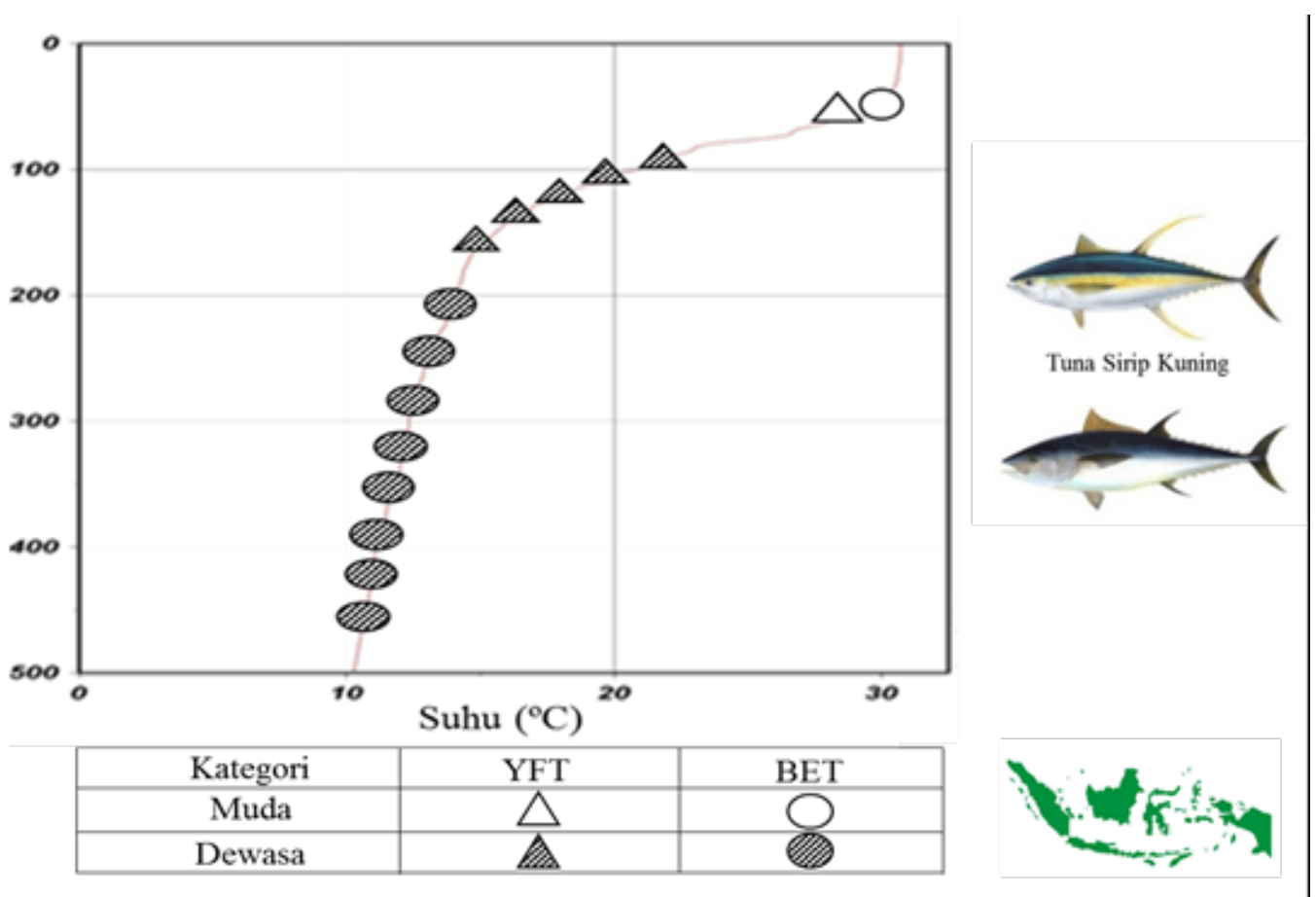

Gambar 1. Sebaran 1kan tuna sirip kuning (yellowfin tuna, YFT) dan tuna mata besar (bigeye tuna, BET) menurut suhu perairan dan kedalaman renang (swimming layer) tertangkapnya, menurut Nurdin (2017), Barata et al. (2011), Nugraha \& Triharyuni (2009), dan Sjarif (2012)

\section{METODE PENELITIAN}

Penelitian ini dilakukan dengan mengumpulkan data hasil tangkapan di lokasi pengoperasian, berada di perairan sekitar pulau Mentawai. Penelitian berlangsung selama 12 hari pada tanggal 1830 Juli 2016, dengan kapal ikan berukuran 29 GT. Adapun lokasi penelitian disajikan pada Gambar 2.

Peralatan yang digunakan dalam penelitian adalah 4 jenis pancing ulur yang berbeda panjang tali $(45 \mathrm{~m}, 53 \mathrm{~m}, 60 \mathrm{~m}$ dan $68 \mathrm{~m}$ ) untuk menangkap tuna, pancing apollo untuk menangkap cumi umpan. Semua pancing ulur adalah milik nelayan namun pancing ulur dengan tali $68 \mathrm{~m}$ adalah alat penelitian yang disediakan peneliti. Alat ukur adalah timbangan gantung jenic clockface dengan kapasitas maksimum $100 \mathrm{~kg}$, alat pengukur panjang ikan dengan kapasitas 40 m, 1 unit termometer. Posisi lokasi penangkapan ikan ditentukan dengan GPS yang terpasang di kapal ikan. Bahan penelitian ini adalah ikan tuna yang tertangkap di lokasi penelitian.

Jenis data yang dipakai dalam penelitian ini adalah jenis ikan, berat, panjang, kedalaman ikan tertangkap, dan Suhu Permukaan Laut (SPL) serta posisi penangkapan ikan. Berikut penjelasan singkat tentang cara pengumpulan setiap jenis data tersebut:

1. Jenis ikan dilihat dengan mengetahui morfologi ikan tuna mata besar dan sirip kuning berdasarkan para ahli.

2. Berat ikan diperoleh dengan menggunakan timbangan clockface scale, yang diukur oleh nelayan tuna di atas kapal dengan cara menggantungkan ikan ditimbang. Ikan yang ditimbang tersebut sudah bersih tanpa isi perut.

3. Panjang ikan forklength (FL) diukur mulai dari ujung kepala hingga cagak ekor dengan menggunakan alat pengukur (meteran).

4. Kedalaman ikan tertangkap diperkirakan dari panjang tali pancing yang diturunkan. Tali pancing yang dipakai nelayan memiliki tanda-tanda skala: satu tanda untuk 30 depa pertama yang diturunkan, kemudian satu tanda setiap 5 depa tali berikutnya. Mengingat pancing ini menggunakan umpan berupa cumi hidup, maka posisi pancing dapat berkisar dari sejauh panjang tali hingga $30 \mathrm{~m}$ lebih dangkal dari panjang tali (Gambar 3). Sebagai contoh, posisi pancing dari pancing ulur dengan panjang tali $45 \mathrm{~m}$ adalah $15-45 \mathrm{~m}$.

5. Suhu permukaan laut insitu diukur dengan mencelupkan sebuah termometer 
air selama 5 menit. Termometer tersebut digantungkan pada tali yang diikat pada sebatang bambu yang panjangnya $1 \mathrm{~m}$. Lokasi pengukuran adalah di pinggir kapal untuk menghindari air pendingin mesin. Data SPL di sekitar Kepulauan Mentawai diperoleh dari Ocean Color Web (https://oceancolor.gsfc.nasa.gov). Data diolah dengan perangkat SeaDAS dan Microsoft Excel.

\section{Analisis data}

Ikan YFT dan BET yang tertangkap selama penelitian dibedakan menjadi 2 kategori, yaitu ikan dewasa dan ikan muda, sesuai dengan kriteria yang dibuat oleh WWF (2015). Ikan digolongkan dewasa jika $\mathrm{FL}>100 \mathrm{~cm}$ dan digolongkan muda jika FL $<100 \mathrm{~cm}$. Ikan-ikan muda dianggap tidak layak tangkap karena pertimbangan belum melakukan reproduksi yang penting bagi menjamin keberlanjutan populasi ikan.

SPL hasil pengukuran insitu dibandingkan dengan SPL kawasan dari citra satelit NOAA. Perbandingan ini bertujuan untuk melihat konsistensi di antara data SPL yang berbeda sumbernya. Selanjutnya, hubungan antara SPL insitu dengan hasil tangkapan dieksplorasi dengan cara menampilkannya dalam sebuah grafik. Eksplorasi ini bertujuan untuk mengidentifikasi bentuk hubungan di antara SPL dan hasil tangkapan tuna, baik tuna muda maupun tuna dewasa.

Sebaran ikan menurut kedalaman ikan tertangkap dieksplorasi untuk mengidentifikasi bukti pengaruh dari penggunaan lampu sebagai alat bantu penangkapan yang merubah pola umum sebaran vertikal tuna yang biasa dilaporkan. Pola umum sebaran vertikal tersebut adalah tuna muda cenderung berada di lapisan dangkal dan tuna dewasa berada di lapisan termoklin (Pickard \& Emery 1990).

Data jumlah seluruh tuna yang tertangkap, jumlah tuna dewasa dan jumlah berat seluruh tuna yang tertangkap dari setiap jenis pancing yang berbeda panjang tali dianalisis untuk menentukan pancing dengan panjang tali terbaik. Untuk setiap jenis data tersebut, jenis pancing dengan nilai tertinggi diberi skor 3 , yang paling rendah diberi skor 1 sedangkan yang bernilai diantaranya diberi skor 2. Selanjutnya, untuk setiap jenis pancing, dilakukan penjumlahan setiap skor masing-masing untuk jumlah seluruh tuna yang tertangkap, jumlah tuna dewasa dan jumlah berat tuna yang tertangkap (Tabel 1). Jenis pancing dengan jumlah skor tertinggi digolongkan sebagai pancing terbaik.

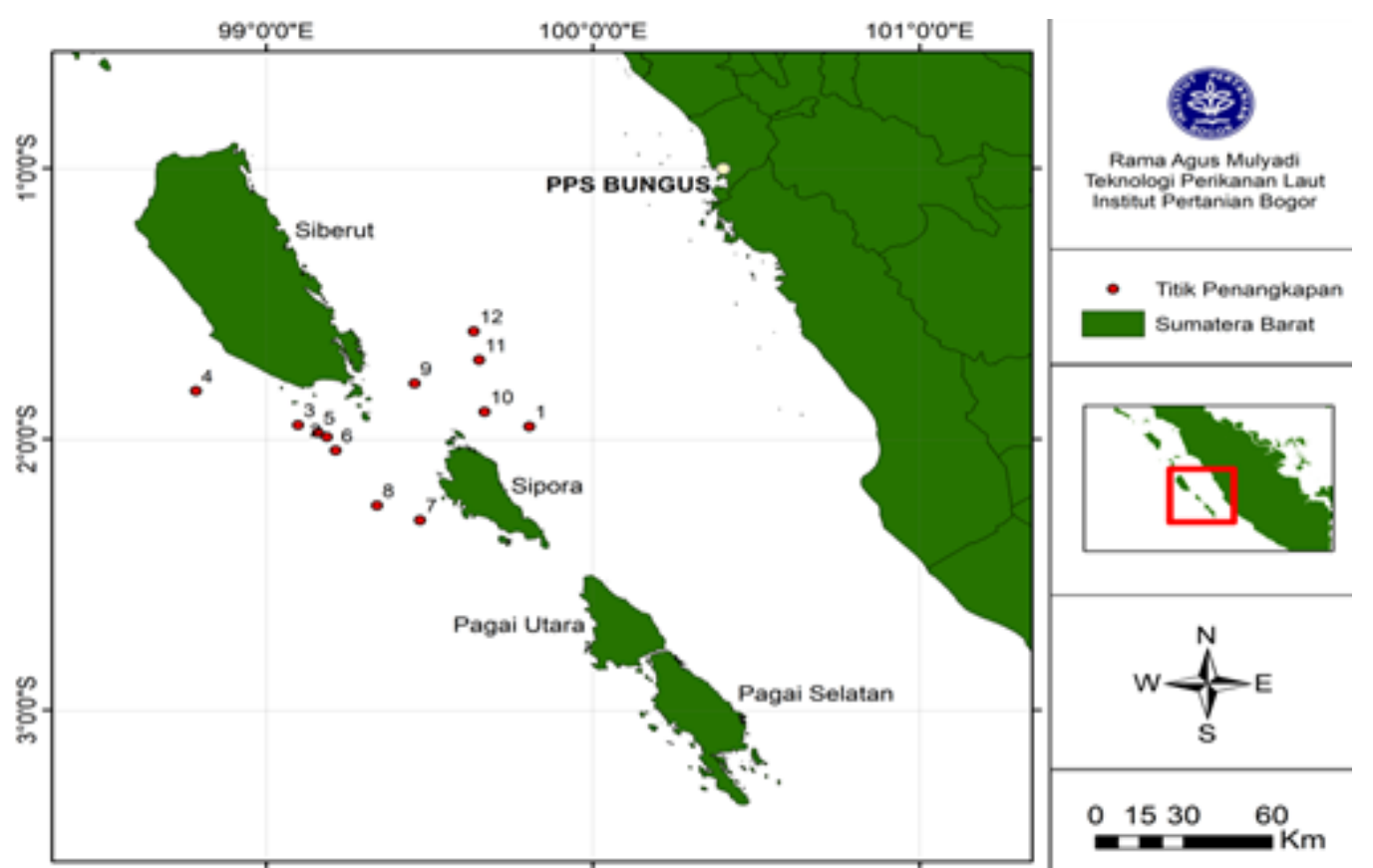

Gambar 2. Lokasi penelitian dan posisi satu trip operasi kapal pancing ulur pada tanggal 1830 Juli 2016 di perairan Pulau Mentawai 


\section{Pancing yang diturunkan}

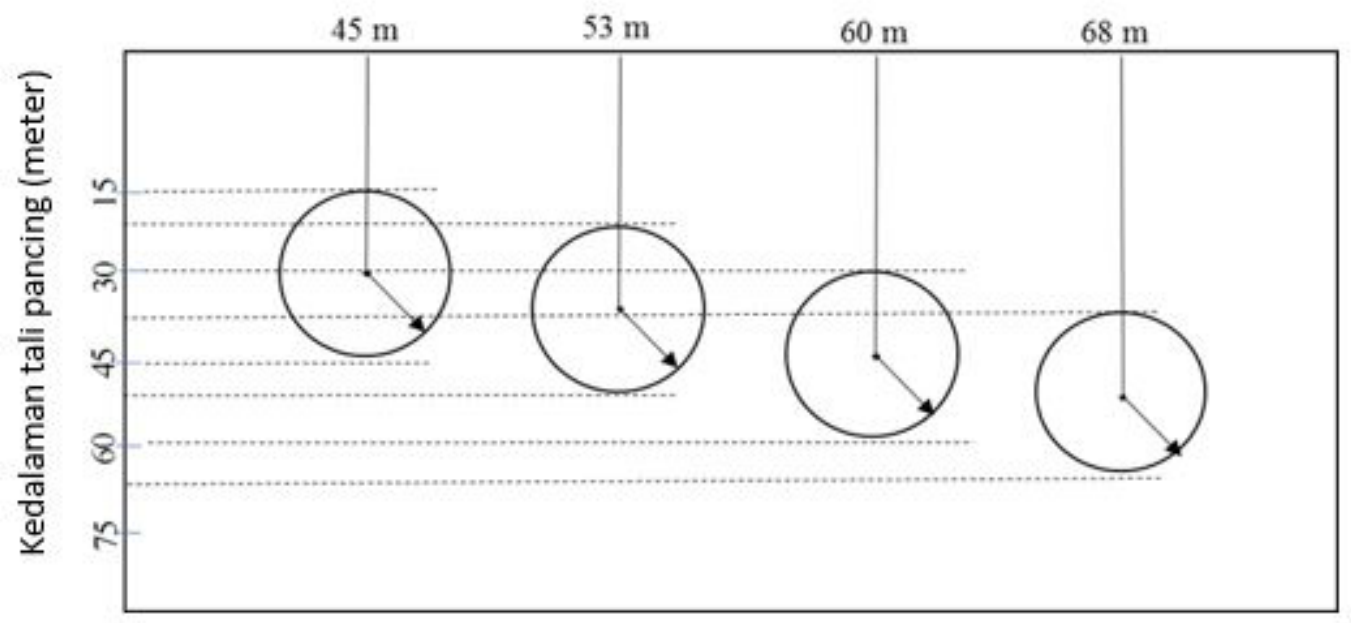

Gambar 3. Kedalaman mata pancing dari 4 jenis pancing ulur yang berbeda panjang tali pancing (A: $45 \mathrm{~m}$, B: $53 \mathrm{~m}, \mathrm{C}: 60$ dan D: $68 \mathrm{~m}$ )

Tabel 1. Perhitungan untuk menentukan jenis pancing terbaik

\begin{tabular}{|c|c|c|c|c|}
\hline \multirow{2}{*}{ Indikator } & \multicolumn{4}{|c|}{ Panjang tali pancing (meter) } \\
\hline & 45 & 53 & 60 & 68 \\
\hline 1. Jumlah seluruh tuna yang tertangkap & $\mathrm{P} 1.1$ & P2.1 & P3.1 & $\mathrm{P} 4.1$ \\
\hline 2. Jumlah tuna dewasa & $\mathrm{P} 1.2$ & P2.2 & P3.2 & P4.2 \\
\hline 3. Jumlah berat seluruh tuna yang tertangkap & $\mathrm{P} 1.3$ & P2.3 & P3.3 & P4.3 \\
\hline Jumlah skor & $\sum_{i=1, j=1}^{3.1} F$ & $\sum_{1, j=2}^{3.2} P$ & $\sum_{1, j=3}^{3.3} P$ & $\sum_{=1, j=4}^{3.4} P$ \\
\hline
\end{tabular}

\section{HASIL DAN PEMBAHASAN}

\section{Suhu permukaan laut}

Suhu permukaan laut (SPL) hasil pengukuran ketika penangkapan ikan dilakukan adalah $27.80{ }^{\circ} \mathrm{C}-30.20{ }^{\circ} \mathrm{C}$ dengan rata-rata $28.97{ }^{\circ} \mathrm{C} \pm 0.68{ }^{\circ} \mathrm{C}$. Menurut data dari citra satelit NOAA, ratarata SPL adalah $27.07{ }^{\circ} \mathrm{C}-29.57{ }^{\circ} \mathrm{C}$ dengan rata-rata $28.29^{\circ} \mathrm{C} \pm 0.75{ }^{\circ} \mathrm{C}$. Nilai rata-rata SPL dari dua sumber tersebut tidak berbeda nyata (Gambar 4). Suhu permukaan laut di lokasi penelitian termasuk ke dalam kondisi lingkungan yang disukai ikan tuna; menurut FAO (2003), suhu air yang disukai tuna adalah $18{ }^{\circ} \mathrm{C}-31^{\circ} \mathrm{C}$ (FAO 2003).

\section{Hasil tangkapan}

Nelayan berhasil menangkap 15 ekor tuna selama penelitian, yang terdiri dari 12 ekor tuna dewasa (120-140 cm, FL) dan 3 ekor tuna muda $(40 \mathrm{~cm}, 42 \mathrm{~cm}$ dan $45 \mathrm{~cm}$ FL). Memperhatikan SPL selama penelitian, data jumlah tuna yang tertangkap tidak menunjukkan suatu pola hubungan antara hasil tangkapan dan SPL, baik untuk tuna dewasa maupun tuna muda (Gambar 5). Untuk sementara, dapat dikatakan bahwa data yang diperoleh dari penelitian ini tidak berhasil menunjukkan adanya pengaruh SPL terhadap hasil tangkapan tuna. Hal ini dapat terjadi karena rangsangan yang ditimbulkan oleh cahaya lampu lebih kuat dari faktor SPL. Selain itu, SPL dan suhu di bawahnya pada lapisan dangkal termasuk suhu lingkungan normal YFT dan BET. Itulah sebabnya tuna tersebut tertangkap ke lapisan dangkal pada kedalaman $45 \mathrm{~m}, 53$ $\mathrm{m}, 60 \mathrm{~m}$, dan $68 \mathrm{~m}$.

Nelayan pancing ulur berhasil menangkap 12 ekor YFT dan 3 ekor BET (Tabel 2). Komposisi jenis tuna dan kategori tuna yang tertangkap oleh setiap jenis pancing ulur tidak selalu sama (Tabel 2). Pancing dengan panjang tali $53 \mathrm{~m}$ berhasil menangkap YFT terbanyak (8 ekor) dengan total berat sebesar $354 \mathrm{~kg}$ sedangkan pancing dengan panjang tali $68 \mathrm{~m}$ tidak 
berhasil menangkap tuna.

Hasil tangkapan tuna didominasi oleh tuna dewasa, yaitu $80 \%$ dari 15 ekor tuna yang tertangkap selama penelitian (Tabel 2). Baik tuna dewasa maupun tuna muda tertangkap pada perairan dengan SPL yang tidak berbeda (dalam kisaran 27.80 ${ }^{\circ} \mathrm{C}-30.20{ }^{\circ} \mathrm{C}$ ) namun tuna muda hanya ditemukan pada SPL $28.70{ }^{\circ} \mathrm{C}$ (Gambar 6). Tuna muda selama penelitian hanya tertangkap oleh pancing dengan panjang tali $45 \mathrm{~m}$, atau kedalaman $15 \mathrm{~s} / \mathrm{d} 45 \mathrm{~m} .12$ ekor tuna dewasa, satu ekor YFT tertangkap oleh pancing dengan panjang tali $45 \mathrm{~m}$. Sementara, tuna dewasa lainnya tertangkap oleh pancing dengan panjang tali $53 \mathrm{~m}$ dan $60 \mathrm{~m}$. Hal ini berarti swimming layer tuna dewasa (baik YFT maupun BET) selama penelitian berada pada kedalaman 23-60 m (Gambar 6).

\section{Pancing terbaik}

Berdasarkan tiga jenis data yang dipakai, yaitu jumlah seluruh tuna yang tertangkap, jumlah tuna dewasa dan jumlah berat seluruh tuna yang tertangkap, jenis pancing yang terbaik adalah pancing dengan panjang tali $53 \mathrm{~m}$ (Tabel 3).

Tertangkapnya tuna dewasa di lapisan dangkal memberikan indikasi bahwa lampu yang digunakan nelayan mampu menaikkan posisi swimming layer tuna dewasa menjadi lebih dekat ke permukaan. Banyaknya hasil tangkapan tuna di kedalaman $53 \mathrm{~m}$ diduga merupakan daerah yang pencahayaannya disukai atau batasan cahaya yang disenangi oleh tuna dewasa, yang mana menurut Nikonorov (1975) bahwa ketertarikan ikan terhadap cahaya akan berbeda-beda tergantung dari ukuran dan spesiesnya.

Penggunaan lampu dapat membangun suatu rantai makanan (temporary food chain) dari zooplankton dan ikan-ikan kecil yang selanjutnya di makan oleh ikan besar, oleh sebab itu umpan yang digunakan harusnya umpan yang disukai tuna, adapun umpan yang digunakan nelayan ialah umpan cumicumi hidup yang dapat bergerak menjadikan ikan tuna tertarik untuk memakannya karena tuna yang bersifat (visual predator), berdasarkan pengalaman nelayan cumicumi merupakan umpan yang disukai oleh tuna, hal ini juga diperkuat dalam penelitian Barata et al. (2011) menyatakan bahwa umpan cumi-cumi merupakan umpan yang banyak di makan tuna dari jenis umpan lainnya.

Dominasi YFT dalam hasil tangkapan ini kemungkinan besar berkaitan dengan posisi swimming layer tuna yang mana tuna mata besar berada lebih dalam dari tuna sirip kuning, kedalaman pancing yang digunakan tergolong lapisan dangkal (Barata et al. 2011). Tetapi perlu diingat bahwa swimming layer tuna yang berukuran besar pada malam hari juga cenderung berada di lapisan atas (Howell et al. 2010; Walli et al. 2009; Maury 2005). Hal ini juga yang menyebabkan mengapa nelayan Bungus selalu menggunakan pancing ulur dengan panjang tali maksimum $60 \mathrm{~m}$, sebagaimana terlihat dari hasil tangkapan pancing dengan panjang tali $53 \mathrm{~m}$. Oleh karena itu, penelitian selanjutnya masih diperlukan untuk menguji hipotesis ini.

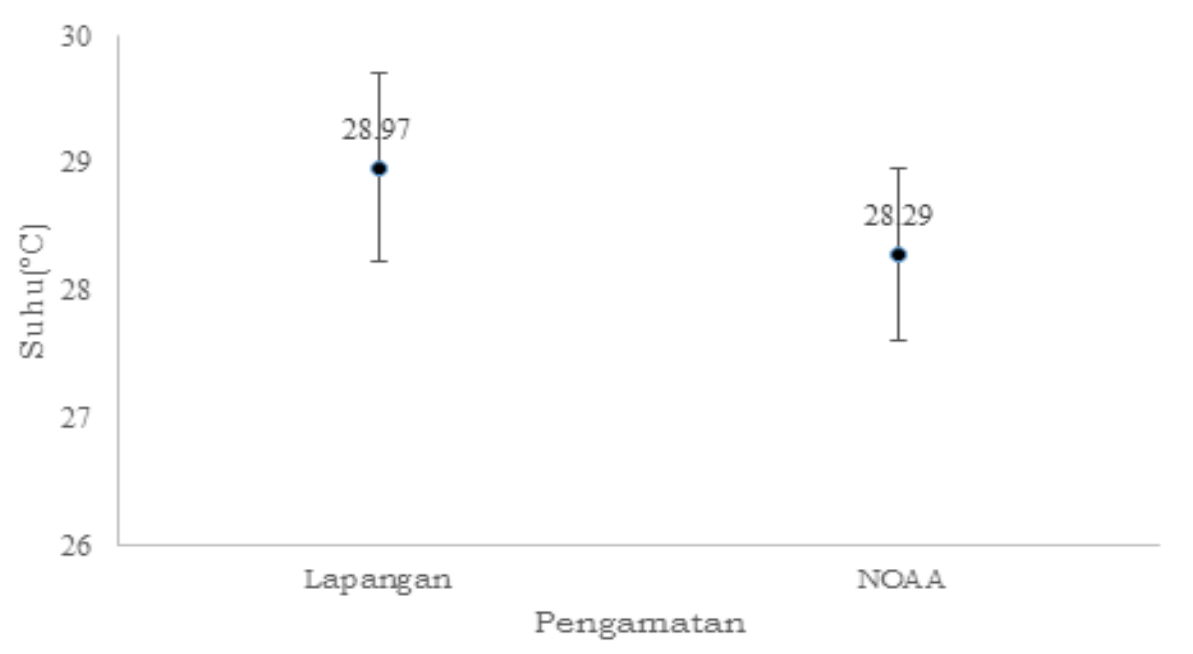

Gambar 4. Rata-rata suhu permukaan laut hasil pengukuran di lapangan (SPL Lapangan) dan pengolahan citra satelit (SPL NOAA) selama satu trip operasi kapal pancing ulur pada tanggal 18-30 Juli 2016 di perairan Pulau Mentawai 


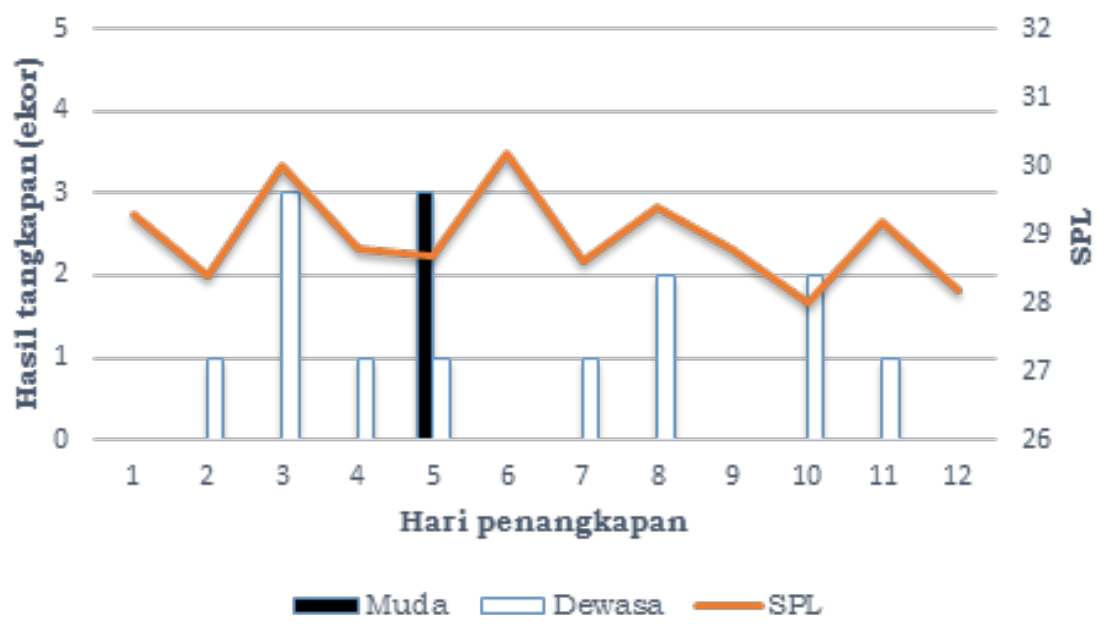

Gambar 5. Hasil tangkapan tuna dewasa dan tuna muda serta suhu permukaan laut hasil pengukuran di lapangan selama satu trip operasi kapal pancing ulur pada tanggal 18-30 Juli 2016 di perairan Pulau Mentawai

Tabel 2. Hasil tangkapan tuna (ekor dan berat) dari 4 jenis pancing dengan panjang tali berbeda selama satu trip operasi kapal pancing ulur pada tanggal 18-30 Juli 2016 di perairan Pulau Mentawai. BET: tuna mata besar (T. obesus), YFT: tuna sirip kuning (T. albacares)

\begin{tabular}{ccccccccccc}
\hline & $\begin{array}{c}\text { Panjang } \\
\text { tali } \\
\text { No }\end{array}$ & \multicolumn{1}{c}{$\begin{array}{c}\text { Jumlah (ekor) } \\
\text { (meter) }\end{array}$} & $\begin{array}{c}\text { BET } \\
\text { muda }\end{array}$ & $\begin{array}{c}\text { BET } \\
\text { dewasa }\end{array}$ & $\begin{array}{c}\text { Total } \\
\text { BET }\end{array}$ & $\begin{array}{c}\text { YFT } \\
\text { muda }\end{array}$ & $\begin{array}{c}\text { YFT } \\
\text { dewasa }\end{array}$ & $\begin{array}{c}\text { Total } \\
\text { YFT }\end{array}$ & BET & YFT \\
\hline 1 & 45 & 2 & 0 & 2 & 1 & 1 & 2 & 5.3 & 43.0 \\
2 & 53 & 0 & 0 & 0 & 0 & 8 & 8 & 0.0 & 354.0 \\
3 & 60 & 0 & 1 & 1 & 0 & 2 & 2 & 45.0 & 71.0 \\
4 & 68 & 0 & 0 & 0 & 0 & 0 & 0 & 0.0 & 0.0 \\
\hline & Total & 2 & 1 & 3 & 1 & 11 & 12 & 53.3 & 468.0 \\
\hline
\end{tabular}

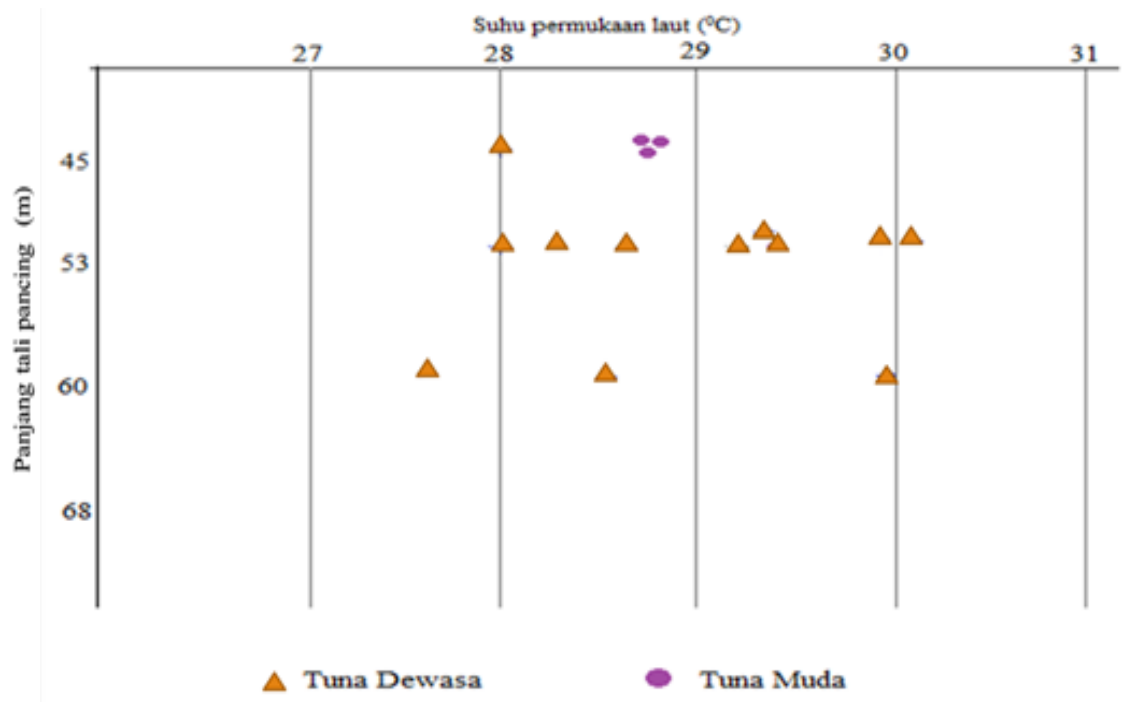

Gambar 6. Sebaran tuna muda dan tuna dewasa berdasarkan suhu permukaan laut dan kedalaman selama Hasil tangkapan tuna (ekor dan berat) dari 4 jenis pancing dengan panjang tali berbeda selama satu trip operasi kapal pancing ulur pada tanggal 18-30 Juli 2016 di perairan Pulau Mentawai. BET: tuna mata besar ( $T$. obesus), YFT: tuna sirip kuning (T. albacares) 
Tabel 3. Penilaian 4 jenis panjang pancing ulur berdasarkan 3 indikator

\begin{tabular}{lcccc}
\hline \multirow{2}{*}{ Indikator } & \multicolumn{4}{c}{ Panjang Tali Pancing (meter) } \\
\cline { 2 - 5 } & $\mathbf{4 5}$ & $\mathbf{5 3}$ & $\mathbf{6 0}$ & $\mathbf{6 8}$ \\
\hline 1. Jumlah seluruh tuna yang tertangkap & 2 & 3 & 1 & 0 \\
2. Jumlah tuna dewasa & 1 & 3 & 2 & 0 \\
3. Jumlah berat seluruh tuna yang tertangkap & 1 & 3 & 2 & 0 \\
\hline \multicolumn{1}{c}{ Jumlah } & & & & \\
\hline
\end{tabular}

\section{KESIMPULAN DAN SARAN}

\section{Kesimpulan}

1. Kondisi SPL selama penelitian menurut pengukuran insitu adalah $27.80{ }^{\circ} \mathrm{C}$ SS30.20 ${ }^{\circ} \mathrm{C}$ dengan rata-rata $28.97{ }^{\circ} \mathrm{C} \pm$ $0.68^{\circ} \mathrm{C}(\mathrm{SD})$. Tuna sirip kuning dan mata besar dewasa sebagian besar tertangkap di kedalaman 23 - $60 \mathrm{~m}$ sedangkan yang muda tertangkap pada kedalaman 15 $45 \mathrm{~m}$.

2. Ada indikasi pengaruh penggunaan lampu terhadap kenaikan posisi swimming layer tuna dewasa.

3. Pancing ulur terbaik adalah pancing dengan panjang tali $53 \mathrm{~m}$.

\section{Saran}

Penelitian untuk membuktikan pengaruh cahaya dalam meningkatkan posisi swimming layer tuna masih harus dilanjutkan. Panjang tali pancing terbaik dalam kondisi lain belum sama dengan hasil penelitian ini. Rekomendasi panjang tali pancing perlu dibuat oleh Pemerintah dan disepakat oleh para nelayan untuk menghindari tertangkapnya tuna muda (tuna yang tidak layak tangkap), seperti dikhawatirkan akhir-akhir ini.

\section{UCAPAN TERIMA KASIH}

Terima kasih dari lubuk hati paling dalam penulis ucapkan kepada Dr. M. Fedi Alfiadi Sondita M.Sc dan Dr. Roza Yusfiandayani S.Pi selaku pembimbing, yang telah memberikan arahan yang membantu dalam penyelesaian penelitian ini.

\section{DAFTAR PUSTAKA}

Barata A, Novianto D, Bahtiar A. 2011. Sebaran ikan tuna berdasarkan suhu dan kedalaman di Samudera Hindia. Jurnal Ilmu Kelautan Indonesia. 16 (3): 165-170.
Barata A, Bahtiar A, Hartaty H. 2011. Pengaruh Perbedaan Umpan dan Waktu Setting Rawai Tuna Terhadap Hasil Tangkapan Tuna di Samudera Hindia. Jurnal Penelitian Perikanan Laut. Vol.17 (2) : 133-134

Diniah M, Yahya A, Pujiyati S, Parwinia S, Effendy M, Hatta M, Sabri, Rusyadi, Farhan A. 2001. Pemanfaatan sumberdaya tuna cakalang secara terpadu. Makalah Falsafah Sains. Program Pasca Sarjana. Institut Pertanian Bogor. Bogor.

[FAO] Food and Sgriculture Organization of the United Nations. 2003 [Internet]. Thunnus albacares. [Diunduh 2017 Desember 07]. Tersedia pada http:/ / www.fao.org/figis / servlet/ ferd?ds $=$ species\&fid $=2497$

Howell EH, Hawn DR, Polovina JJ. 2010. Spatiotemporal variability in bigeye tuna (Thunnus obesus) dive behavior in the central North Pacific Ocean. Elsevier Ltd. P Oseonog. 86: 81-93.

Maury O. 2005. How to Model the SizeDependent Vertical Behavior of Bigeye (Thunnus obesus) Tuna in Its Environment?. ICCAT. VOL 57 (2): 115-126.

Nakamura H. 1969. Tuna Distribution and Migration. London: Fishing News Book Ltd..

Nikonorov, I.V. 1975. Interaction of Fishing Gear with Fish Aggregation. Keter Publishing. House. Jerusalem Ltd. Israel.

Nurdin E. 2017. Rumpon sebagai alat pengelola perikanan tuna berkelanjutan; Madidihang (Thunnus albacares). [Disertasi]. Bogor (ID) : Institut Pertanian Bogor.

Nugraha B, Triharyuni S. 2009. Pengaruh Suhu dan Kedalaman Mata Pancing Rawai Tuna (Tuna Longline) Terhadap Hasil Tangkapan Tuna di Samudera Hindia. J. Pusat Riset Perikanan Tangkap. Jakarta. 15(3): 239-247.

Pickard GL, Emery WJ. 1990. Descriptive 
Physical Oceanography. Pergamon Press, Oxford.

Sjarif B, Suwardiyono, Gautama SD. 2012. Penangkapan Ikan Dan Penanganan Ikan Tuna Segar di Kapal Rawai Tuna. Balai Besar Pengembangan Penangkapan Ikan. Semarang.

[WWF] World Wide Fund for Nature-Indonesia.
2015. Panduan Penangkapan dan Penanganan ikan. Jakarta Selatan.

Walli A, Teo SLH, Boustany A, Farwell CJ, Williams T. 2009. Seasonal Movements, Aggregations and Diving Behavior of Atlantic Bluefin Tuna (Thunnus thynnus) Revealed with Archival Tags. PLoS ONE. 4(7): 61-51. 